\title{
Socio-Economic Status of Women entrepreneurship - A case study of Morigaon District in Assam.
}

\author{
Ajit Borah. \\ Asstt. Professor of Rukasen College. Department of Economics Bakalia, Karbianglong (Assam)
}

\begin{abstract}
Entrepreneurship has acquired special significance in the context of Indian economic growth in a rapidly changing socio-economic and political climate, particularly in industry. Development is a function of entrepreneurs in today's world of privatization, liberalization and globalization. Entrepreneurship is a creative human act. Therefore, entrepreneurship helps to increase per capital income, standard of living, capital formation in the backward region of the country. It is a process to accelerate economic growth by covering risk, uncertainly, innovation, planning and decision-making. Here, in the research paper, a field based picture of women entrepreneurship of Morigaon district of Assam is presented analyzing their various socio-economic statuses through structured questionnaire
\end{abstract}

Keywords: Entrepreneurs, women entrepreneurship, socio-economic status.

\section{Introduction}

Women entrepreneurship has played a dynamic role in the economic development of region. Women are engaged in agricultural operations, household industries, trade and commerce and other related economic activities. Women are hard workers, adventurous; self determined and are willing to take risks in setting up new enterprises. Though it is a tradition on the part of women to make efficient management of household affairs but now-a-days women are equally interested in setting up their own business to become independent and self reliant. Presently the major problems faced by developing nations of the world including India are, illiteracy, hunger and starvation, poverty, malnutrition, ill-health, unsafe drinking water, low per capita income, population explosion, under employment and unemployment, low agricultural production are productivity, low capital formation and low living standard. There are inequalities in the distribution of existing economic resources. It is women entrepreneurship which helps to a certain extent to check some of the above constraints of development issues. As technology speeds up life, women are becoming an emerging economic force, which cannot be neglected by the policy makers. The world's modern democratic economy depends on the participations of both the sexes, (vasanthagopal, R and Santh, S.2008). Commercialization and modernization of the economy in gradually eliminating many of the employment avenues to women in agriculture and industries and so they have to find various ways of supplementing their family income. As a result of this, a section of the urban and rural human has emerged as potential entrepreneurs (Arvinda, C.H. and S. Renuka, 2001). Today women in advanced market economics own more than 25 percent of all business. In some regions of the world, due to shift to market economy, women entrepreneurship is becoming a growing trend.

Objectives:

\section{Objectives and Hypothesis}

The present study seeks to modest attempt to find out the socio-economic status of women entrepreneurship in the Morigaon district of Assam.

Hypothesis:

The study is based on the hypothesis that the level of education helps women entrepreneurs to start their enterprises.

\section{Methodology}

The methodology applied for the study is illustrated below:

\section{Collection of primary data and information:}

The study is based on primary and secondary data and information. However, Primary data are given more importance as compared to secondary data. The study women entrepreneurs of Morigaon district, a depth survey is undertaken. The primary data are collected through personal interviews, schedules and questionnaires. The questionnaires are shaped with the objective of collecting qualitative information from the said. 


\section{Collection of Secondary data and information:}

Data from the secondary sources include various published and unpublished documents relevant books and journals, newspapers, magazines, electronic media etc. Besides, there, secondary data are also collected from Blocks, SHGs, DIC, DRDA etc. The Secondary data and information are particularly helpful in supporting the sample survey.

\section{Statistical Methods:}

Various statistical methods such as, tables, figures, average, percentage and other related statistical techniques are used to analyze the collected data and information.

\section{Sample design:}

The sampling method chosen for the above research design is random sampling method considering the extensiveness of the study, cost and time factors; it is decided to select 100 women entrepreneurs from Morigaon district. These entrepreneurs are chosen at random from 5 blocks, i.e. Mayong Development Block, Kapili Development Block, Bhurbandha Development Block, Laharighat Development Block, Moirabari Development Block. From each block 20 samples are taken. Hence, the sample sizes 100.

\section{Period of Study:}

The study was carried out from April 2010 to March 2013 for primary data collection. The reference period of survey was 2010-2013 in Morigaon district of Assam.

\section{Results and Discussion}

\section{Age distribution of women entrepreneurs:}

The study of age distribution of entrepreneurs in entrepreneurship study has significance in determining the growth of entrepreneurs of the total population. The growth of women entrepreneurs generally fall within the age group of 15-60 years. The age group distribution of entrepreneurs in the study area is shown in the table 1 . A large number of constraints like illiteracy, religions binding, household bindings, superstition, pardah-pratha, capital deficiency, lack of training are responsible for low level of women entrepreneurs in the economic development process in Morigaon district. However, the scenario of self help group (SHGs) by women section.

Table 1: Age distribution of Respondents

\begin{tabular}{|c|c|c|c|}
\hline Sl. No. & Age group & Frequency & Percentage \\
\hline 1 & Below 25 & 15 & 15.00 \\
\hline 2 & $26-45$ & 71 & 71.00 \\
\hline 3 & $46-60$ & 14 & 14.00 \\
\hline
\end{tabular}

Source: Field Survey.

According to the above table 1, the highest percentage $71 \%$ of women entrepreneurs are recorded in the age group of 26-45 years while the lowest percentage 14\% are recorded in the age group of 14-60 years. The main factors responsible for the emergence of women entrepreneurs in Morigaon district are lack of government jobs, limited sources of family income, motive of self-dependency etc.

\section{Caste-wise distribution of entrepreneurs:}

The population of Morigaon district comprises scheduled caste, scheduled tribe, other backward class (OBC), more other backward class (MOBC) and general caste. It has been found in field survey that $40 \%$ of women entrepreneurs belong to OBC. The lowest percentage of women entrepreneurs among MOBC are religions binding, pardah-patha, low literacy rate, deficiency of capital and household burden only $14 \%$ of the women of general caste prefer to take business avenues owing to better economic position, possession of land assets and jobs. Moreover, the general class of women enjoys high value in the society and therefore they are reluctant to take up business enterprises. In the study area, OBC is dominating due to a number of reasons like family support, financial need of the household, growth of literacy rate etc. The caste-wise distribution of entrepreneurs in the study region is shown in the fig-1 
Fig-1: Caste-wise distribution of women entrepreneurs

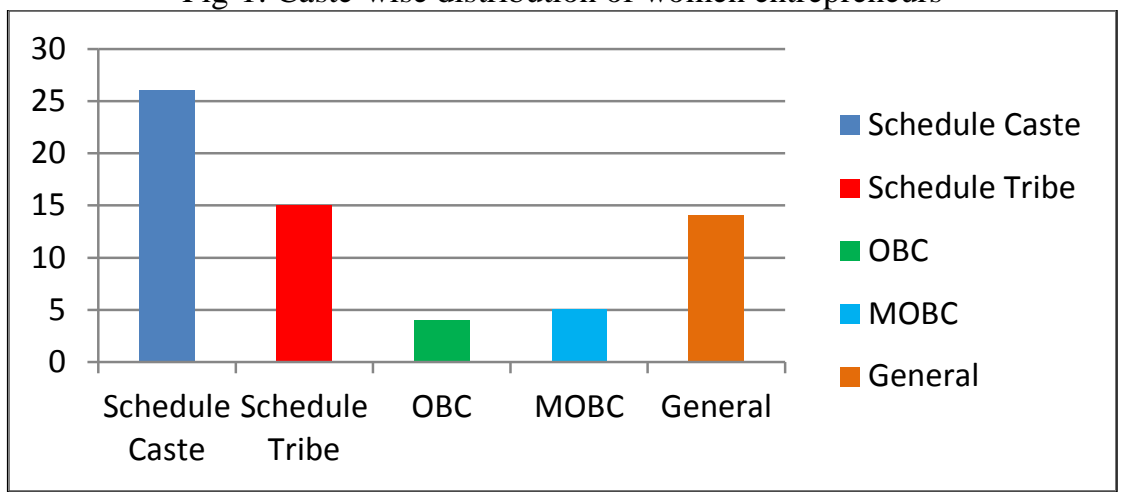

Source: Field Survey.

\section{Religion-wise distribution of entrepreneurs:}

Religion-wise distribution of women entrepreneurs is a very important indicator in entrepreneurship study to analyze the quality women resources in a particular region. It has been found in field survey that $91 \%$ of women entrepreneurs belong to Hindu religion while 9\% belonged to Muslim religion. It has been observed that Hindu women are more free and literate in comparison to Muslim women in setting up business ventures in the district. The religion wise distribution of women entrepreneurs in the study region is depicted in the table 2 .

Table 2 : Religion-wise distribution of women entrepreneurs

\begin{tabular}{|c|c|c|c|}
\hline Sl. No. & Name of the religion & Frequency & Percentage \\
\hline 1 & Hindu & 91 & 91.00 \\
\hline 2 & Muslim & 09 & 9.00 \\
\hline
\end{tabular}

Source: Field Survey.

\section{Educational qualification of entrepreneurs:}

Education is an important aspect of entrepreneurial development programmed. It develops basic skills and abilities and promotes application of new knowledge, innovative ideas to production units of enterprises. It is an asset in accelerating entrepreneurial growth and in ensuring social change in desired directions. It helps to acquire market information purchase of raw-materials, bank finance and quality production. Table 3 shows the educational qualification of women entrepreneurs in Morigaon district.

Table 3 : Educational qualification of the responds.

\begin{tabular}{|c|c|c|c|}
\hline Sl. No. & Educational Qualification & Frequency & Percentage \\
\hline 1 & Illiterate & 10 & 10.00 \\
\hline 2 & Primary School & 05 & 5.00 \\
\hline 3 & Middle School & 06 & 6.00 \\
\hline 4 & High School & 33 & 33.00 \\
\hline 5 & H.S.L.C. Passed & 14 & 14.00 \\
\hline 6 & Higher Secondary & 17 & 17.00 \\
\hline 7 & Under graduate & 02 & 2.00 \\
\hline 8 & Graduate & 12 & 12.00 \\
\hline 9 & Post graduate & 01 & 1.00 \\
\hline
\end{tabular}

Source: Field Survey

Among the entrepreneurs $10 \%$ are illiterate, $33 \%$ up to high school and $1 \%$ up to post graduate level. It is found in field survey that most of the women entrepreneurs prefer to undertake business activities rather to purse higher education probably due to poor economic condition of the rural families on the district.

Occupational distribution of the head of the sample households:

The economic activity of any region will remain incomplete without referring to the occupational structure of the people living therein. Generally, the occupational structure of any economy relates to the distribution of its population according to various occupations. The livelihood of mentioned is the key indicator were all economic activities are concentrated. Therefore, occupational structure is closely related to the development of an economy. The occupation structure of the sample households in the districts is depicted in the Fig 2 
Fig 2 : Percentage distribution of occupation of Head of sample households.

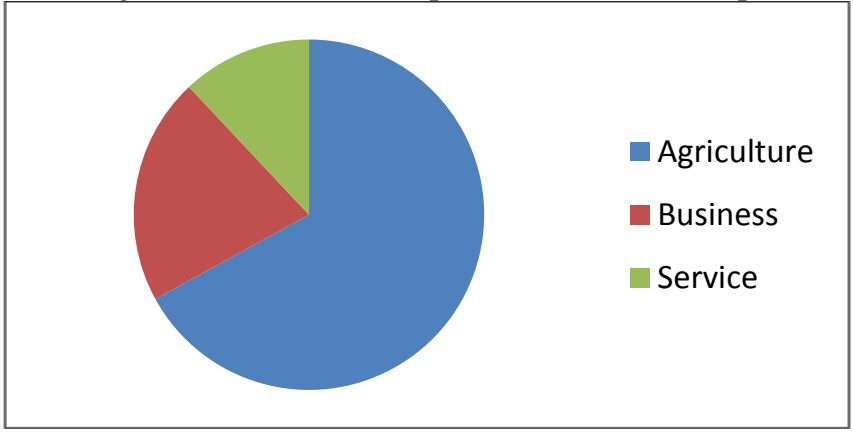

Source: Field Survey

Occupation structure of most of the states of India is generally dominated by the agricultural sector. Following this trend, the economy of Morigaon district has been experiencing the highest percentage of people engaged in agriculture activities. Among the samples households, 67\% are fond to be agriculture as a primary source of livelihood. However, the importance of business and service sectors is no less significant as services of livelihood of rural masses of the study region accounting for $21 \%$ and $12 \%$ respectively.

\section{Dependents of women entrepreneurs:}

Parents and husband occupations are two important indicators to determine women entrepreneurs. It is found in field survey that $58 \%$ women entrepreneurs depend on parents and $42 \%$ depend on husbands. This picture reflects that comparatively large numbers of women entrepreneurs in Morigaon district are unmarried.

\section{Level of income of the head of the sample family:}

Survey of women entrepreneurs in the district brings out the existence of sharp inequalities in income distribution of the head of the sample family. The following finds are significant in this regard. It is found that $18 \%$ of the total sample households earn less that Rs. 10,000 - 15,000 per month. The highest amount of income Rs. 40,000 and above $4 \%$ is earned by the head of the family. Inequalities in land asset distribution, job availability, educational qualification and family size are main causes of unequal distribution of income in the study are. The level of income of the head of the family to depicted in the table 4.

Table 4 : Level of income of the head of the sample family (per month)

\begin{tabular}{|c|c|c|c|}
\hline Sl. No. & Level of income (in Rs.) & Frequency & Percentage \\
\hline 1 & $10,000-15,000$ & 18 & 18.00 \\
\hline 2 & $15001-20,000$ & 25 & 25.00 \\
\hline 3 & $20,001-25,000$ & 35 & 35.00 \\
\hline 4 & $25,001-30,000$ & 12 & 12.00 \\
\hline 5 & $30,001-40,000$ & 06 & 6.00 \\
\hline 6 & 40,000 and above & 04 & 4.00 \\
\hline
\end{tabular}

Source: Field Survey.

\section{Distribution of Family members of responds according to Age and Sex:}

Distribution of family members according to age and sex indicate the burden of household activity, working potential in the family and sex composition of sample respondent. According to the following Table 5, the highest percentage i.e. $28.2 \%$ family members lie in the age group of $7-14$ and the lowest percentage $10.5 \%$ of family members of sample respondent lie in the age group of 60 and above. The highest percentage may be attributed to the growing needs of the families which compel the respondent to take up business activities as a source of earning. The reason behind the lowest percentage can be attributed to the declining needs of the families with increase in age. From the point of sex composition the total numbers of females are layer than the males. It is depicted in the fig 3 
Fig 3 : Distribution of family members of the respondents according to age and sex

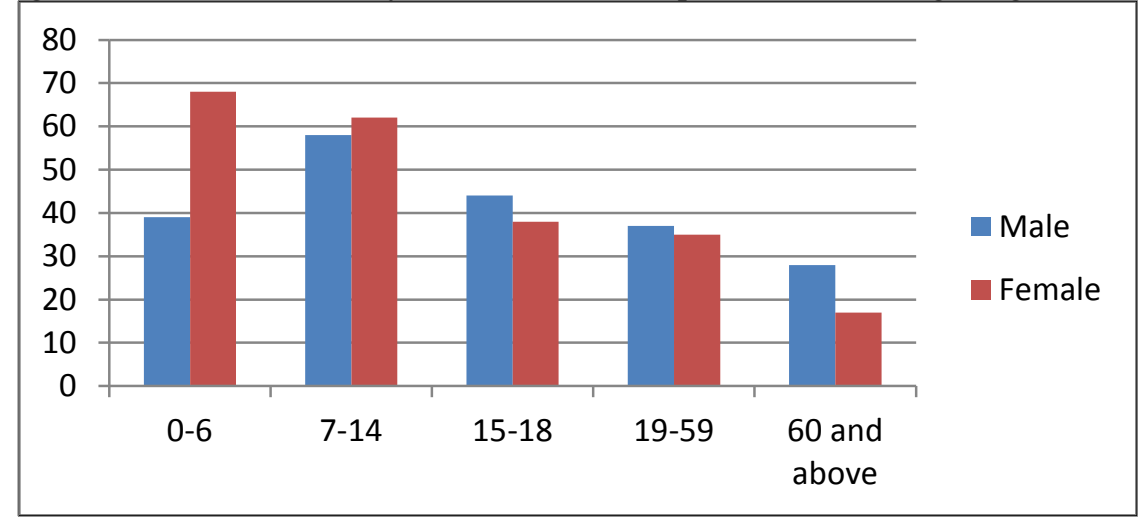

Source: Field Survey.

\section{Number of dependents on the income of the respondents:}

The number of dependents on the income of the responds gives an idea about the nature of the household, that nuclear or joint. According to the table 6 the highest number of women entrepreneurs that is $22 \%$ has to bear expenditure of 10 members in their household. Their families are joint families. The lowest number that is $4 \%$ of women entrepreneurs have to bear the burden of 6 members of their families of their families. Their families are nuclear families. This is shown in the table 5 below.

Table5: Number of dependents on the income of the respondents.

\begin{tabular}{|c|c|c|}
\hline No. of Dependents & Frequency & Percentage \\
\hline 1 & 12 & 12.00 \\
\hline 2 & 10 & 10.00 \\
\hline 3 & 15 & 15.00 \\
\hline 4 & 08 & 8.00 \\
\hline 5 & 10 & 10.00 \\
\hline 6 & 04 & 4.00 \\
\hline 7 & 06 & 6.00 \\
\hline 8 & 05 & 5.00 \\
\hline 9 & 04 & 4.00 \\
\hline 10 & 22 & 22.00 \\
\hline 11 & 04 & 4.00 \\
\hline
\end{tabular}

Source: Field Survey.

\section{Decision makers of the respondents:}

Decision makers of the respondents play pivotal role in starting business makers are their husbands. The reason behind this may be attributed to liberal attitudes of husbands towards their wife's in setting up business establishment to support family source of income. The lowest percentage $8 \%$ of women entrepreneurs decision makers are others. This proves that others may be a source of inspiration for women to start business activities.

Table6: Decision makers of the respondents

\begin{tabular}{|c|c|c|c|}
\hline Sl. No. & Decision makers & Frequency & Percentage \\
\hline 1 & Parents & 17 & 17.00 \\
\hline 2 & Husbands & 20 & 20.00 \\
\hline 3 & Friends & 09 & 9.00 \\
\hline 4 & Relations & 09 & 9.00 \\
\hline 5 & Training Centre's & 15 & 15.00 \\
\hline 6 & DIC & 10 & 10.00 \\
\hline 7 & Bank & 12 & 12.00 \\
\hline 8 & Others & 08 & 8.00 \\
\hline
\end{tabular}

Source: Field Survey.

\section{Types of enterprises taken up by the respondents:}

The type of enterprises started by women entrepreneurs in a particular region reflects their potentiality, interest and demand of the product in the market. Among the various lines of production, weaving units have a predominant place as $28 \%$ of the unit have come under this group weaving is not only an enterprise that also the culture and tradition of Assamese womenfolk weaving is a way of life to Assamese women. One percent of women entrepreneurs are engaged in grocery business. It is observed in field survey that grocery business is run 
Socio-Economic Status of Women entrepreneurship - A case study of Morigaon District in Assam.

by male members of the family. Now-a-days, there is trend among women entrepreneurs to take up business like cutting, tailoring, cloth store, food processing cosmetics, beauty parlous, mushroom cultivation, bamboo and cane works, pottery etc. The types of enterprises taken up by the female entrepreneurs in the study region are illustrated in the table 7

Table 7: Percentage of enterprises taken up by the respondents.

\begin{tabular}{|c|c|c|c|}
\hline Sl. No. & Types of enterprises & Frequency & Percentage \\
\hline 1 & Cutting, tailoring and embroidery & 25 & 25.00 \\
\hline 2 & Weaving & 28 & 28.00 \\
\hline 3 & Cloth store & 06 & 6.00 \\
\hline 4 & Food processing & 18 & 18.00 \\
\hline 5 & Cosmetics & 08 & 8.00 \\
\hline 6 & Beauty parlous & 12 & 12.00 \\
\hline 7 & grocery & 01 & 1.00 \\
\hline
\end{tabular}

Source: Field Survey

\section{Percentage of workers according to enterprises:}

Women enterprises contribute to generate employment avenues in the region. Their enterprises are not only a source of income for them but also source of income for other women workers working with them. The study reveals that 42 percent of enterprises have been using trained workers and 58 percent have been using untrained workers. This indicates that major portion of women entrepreneurs is running their establishments without training.

\section{Sources of finance for the sample enterprises:}

Bank plays an important role in promoting women entrepreneurs in Morigaon district. The establishment of bank branches in an area facilitates business promotion. It also promotes agricultural development setting up new industrial units and trade and commerce. The sources of finance indicate the contribution of various sources to women entrepreneurs in starting business ventures. It is found in field survey that $21 \%$ women entrepreneurs have started their business by their won capital $56 \%$ have started business from SHGs capital and $15 \%$ have started using finance supplied by RRBs and $8 \%$ of them have started by using finance of Nationalized Banks. This is representing by the fig 4 below.

Fig 4 : Percentage distribution of sources of finance

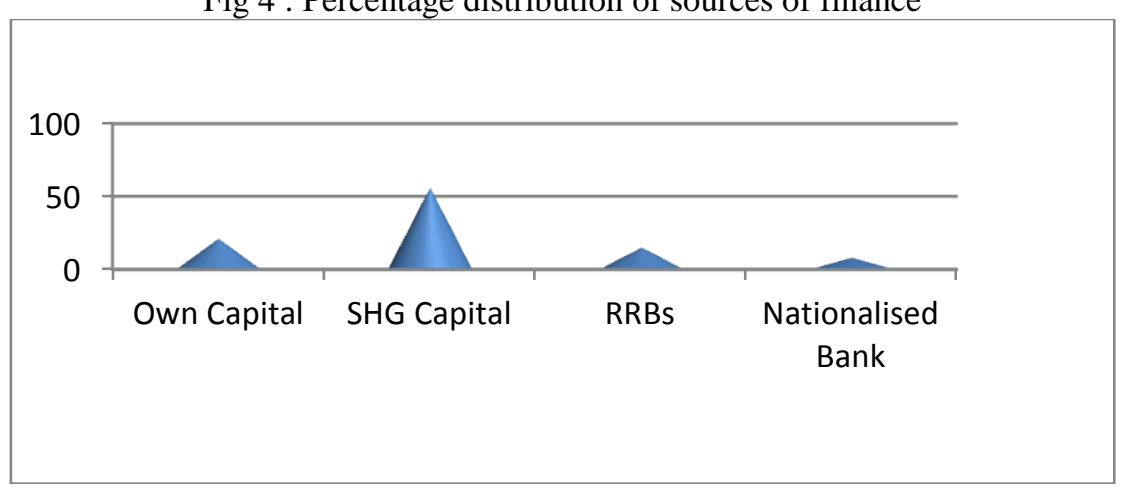

Source: Field Survey

\section{Investment in Fixed capital by the sample units:}

Capital is the produced means of production. It is created by men and is used for further production. Fixed capital is that capital. This does not change its form after repeated use in the production process. Every enterprise unit requires investment in fixed as well as working capital. Fixed capital is the first requirement to start a business enterprise. According to the table 8, the largest number of enterprises $16 \%$ have their business with a fixed capital between Rs. 10,001-20,000. It is not a heavy amount to start a business enterprise $12 \%$ of women entrepreneurs have started business activities with a meager amount of Rs. 100-1000, 13\% of entrepreneurs have started enterprise with the amount between Rs. 1,001-10,000 and 10\% of entrepreneurs have started enterprise with the amount between Rs. 20,001-30,000. This picture indicates that women entrepreneurs can start business with a small amount of capital if they are interested in this line. The investment in fixed capital by the sample units is shown in the table 8 . 
Socio-Economic Status of Women entrepreneurship - A case study of Morigaon District in Assam.

Table8: Investment in fixed capital by the sample units.

\begin{tabular}{|c|c|c|c|}
\hline S1. No. & Fixed capital (in thousands) & Frequency & Percentage \\
\hline 1 & $100-1000$ & 12 & 12.00 \\
\hline 2 & $1001-10000$ & 13 & 13.00 \\
\hline 3 & $10001-20000$ & 16 & 16.00 \\
\hline 4 & $20001-30000$ & 10 & 10.00 \\
\hline 5 & $30001-40000$ & 08 & 8.00 \\
\hline 6 & $40001-50000$ & 08 & 8.00 \\
\hline 7 & $50001-60000$ & 04 & 4.00 \\
\hline 8 & $60001-70000$ & 08 & 8.00 \\
\hline 9 & $70001-80000$ & 06 & 6.00 \\
\hline 10 & $80001-90000$ & 05 & 5.00 \\
\hline 11 & $90001-100000$ & 05 & 5.00 \\
\hline 12 & 100000 -and above & 05 & 5.00 \\
\hline \multicolumn{2}{|r|}{} \\
\hline
\end{tabular}

Source: Field Survey

Monthly turnover of the sample enterprises:

Monthly turnover reflects source of inspiration and confidence for the women entrepreneurs to carry out their business. By investing more, if less turnover is earned, it may reduce the continually of business. According to the fig 5, the majority of the women enterprises 33\% earned between Rs. 500-1500 per month. This monthly turnover is very meager but still they are willing to run their enterprises expecting that the future turnover will improve only one percent of entrepreneur monthly turnover is Rs. 15,000 and above. This is an exceptional case found in the field study. This is the only enterprise in Morigaon district which is specialized in garage, welding and supply of oxygen gas. This enterprise has been speedily expanding due to efficient management, well trained staff and marketing skill. The monthly turnover of the sample enterprises is shown in the fig. 5

Fig 5 : Monthly turnover of the sample enterprises

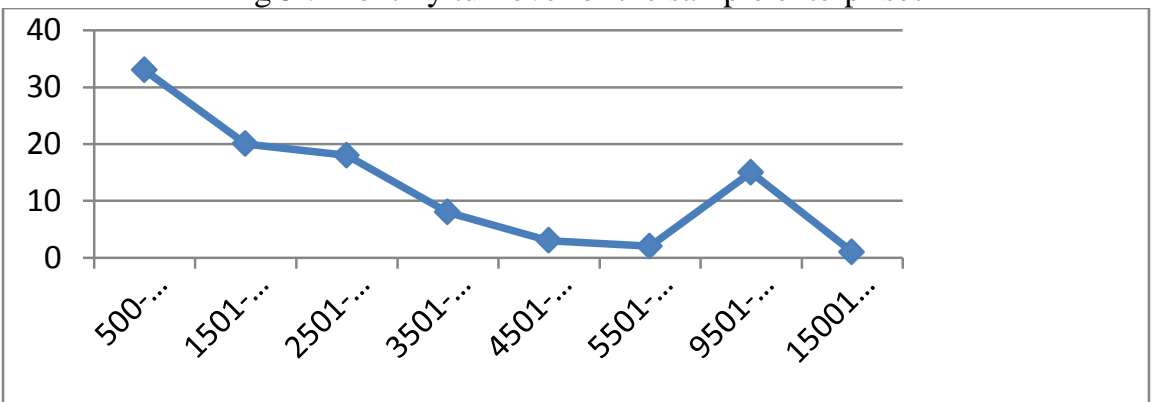

Source: Field Survey.

\section{Terms of sales of the enterprises:}

Generally entrepreneurs sell their products and cash terms. But in case of small women enterprises, sales sometimes are done on credit term also. According to field study, report 33 percentage of the entrepreneur's sale their products on credit terms for one to three months on the other hand, 67 percentages of the entrepreneurs sell their product on cash basis. So, there is preponderance of both cash and credit in terms of sale.

\section{Price fixation for the products:}

Nature of price fixation indicates the size of business enterprises. Usually large business enterprises fix the prices of their products on whole sale basis and small enterprise fixes the prices of products on retail basis. It is found in field survey that only 8 percent of women entrepreneurs charge wholesale price, 46 percent charge retail prices and 46 percent did not specify the type of price charged for their products.

\section{Motive of starting business:}

Motive of starting business enterprises by the women entrepreneurs are many like source of income to the family self dependent to fulfill creative urge, family inspiration and non-availability of alternative source of income. The table 10 shows that 39 percent of women entrepreneurs have started business to earn income either to assist their husband or their parents $43 \%$ of them have started business enterprises to be self dependent, 3 percent of them have started business to fulfill creative urge, 5 percent of them have started business due to family inspiration and 10 percent of them have started enterprises due to non-availability of alternative source of to the family. The motive of starting business by women entrepreneurs is shown in the table 9below. 
Socio-Economic Status of Women entrepreneurship - A case study of Morigaon District in Assam.

Table9: Motive of starting business

\begin{tabular}{|c|c|c|c|}
\hline Sl. No. & Motive & Frequency & Percentage \\
\hline 1 & Source of income to the family & 39 & 39.00 \\
\hline 2 & To be self-dependent & 43 & 43.00 \\
\hline 3 & To fulfill creative urge & 03 & 3.00 \\
\hline 4 & Family inspiration & 05 & 5.00 \\
\hline 5 & Non-availability of alternative source of income & 10 & 10.00 \\
\hline
\end{tabular}

Source: Field Survey.

\section{Factors contributing for the success of the enterprises:}

The success of business enterprises depend on various factors. These factors vary from enterprise to enterprise. It is found from the field study that 15 percent of women business enterprises become successful due to known business responsibility and sacrifice, so percent became successful due to contract with many people, 21 percent became successful due to planned approach, 31 percent became successful due to hard labour and 5 percent became successful as they are careful in financial management of the enterprises. Factors contributing for the success of the enterprises are shown in the table 10below.

Table10: Factors contributing for the success of the enterprises

\begin{tabular}{|c|c|c|c|}
\hline Sl. No. & Factor & Frequency & Percentage \\
\hline 1 & Responsibility and sacrifice & 15 & 15.00 \\
\hline 2 & Contract with many people & 10 & 10.00 \\
\hline 3 & Family support & 21 & 21.00 \\
\hline 4 & Planned Approach & 18 & 18.00 \\
\hline 5 & Hard Labour & 31 & 31.00 \\
\hline 6 & Economy & 05 & 5.00 \\
\hline
\end{tabular}

Source: Field Survey

\section{Conclusion}

It has been observed from the above analysis that socio-economic factors influence women in making a successful entrepreneur. The overall analysis of these variables establishes that socio-economic status of the surveyed women entrepreneurs in the district was above average and the hypothesis set that the growth of women entrepreneurs depend on the educational qualification acquired by them. It is found that $80 \%$ of women entrepreneurs in the study region have educational qualification. Therefore, it is accepted. However, it is observed in data analysis that women entrepreneurs in the district need training, financial support marketing network to sell their products. For the sustainable development of women enterprises, a new time oriented govt. policy is required.

\section{References}

[1]. Vasanthagopal, R and Santha, S (2008), women entrepreneurship in India, New century publication, New Delhi, Pp. 1-5.

[2]. Arvinda, C.H. and S, Renuka (2001), women entrepreneurs: An exploratory study, SEDME, Sept. P 71.

[3]. Vasanthagopal, R and Santha, S (2008), op.cit, P 1.

[4]. Chattopadhyay, Arundhati (2005), women and entrepreneurship, Yojana, January, Pp 27-33

[5]. Khan, Noman Shibly A.M.M. (2009), women micro entrepreneurship and social capital in Bangladesh, SEDME, March, 36.1 